\title{
Skrining Fitokimia dan Aktivitas Antidiabetes dalam Ekstrak Daun Nasi (phrynium Capitatum)
}

\author{
Obet Obet $^{1}$, Johnly A. Rorong ${ }^{1}$, Feti Fatimah ${ }^{1}$ \\ ${ }^{1}$ Program Studi Kimia, FMIPA, Universitas Sam Ratulangi, Manado
}

\begin{abstract}
ABSTRAK
Telah dilakukan penelitian skrining fitokimia dan aktivitas antidiabetes dalam ekstrak daun nasi (Phrynium capitatum). Tujuan penelitian ini untuk mengetahui keberadaan fitokimia dan aktivitas antidiabetes dalam ekstrak daun nasi. Metodologi penelitian yang digunakan pada skrining fitokimia yaitu pengujian alkaloid, fenolik, flavonoid, saponin, steroid dan triterpenoid. Sedangkan pengujian aktivitas antidiaetes dilakukan perlakuan pada tikus putih yang di induksi aloksan. Berdasarkan pengujian skrining fitokimia dari ekstrak daun nasi diperoleh komponen senyawa alkaloid, flavonoid, fenolik dan steroid. Hasil pengujian aktivitas antidiabetes ekstrak daun nasi pada tikus yang di induksi aloksan dengan pemberian ekstrak daun nasi konsentrasi 100; 200 dan $300 \mathrm{mg} / \mathrm{kg}$ berat badan tikus memiliki persen penurunan konsentrasi gula darah berturut-turut $29.01 ; 34.07$ dan $42.03 \%$. Kelompok yang paling efektif memberikan efek antidibetes adalah kelompok perlakuan III (300 mg/kg berat badan tikus) bila dibandingkan dengan kelompok perlakuan I (100 $\mathrm{mg} / \mathrm{kg}$ berat badan tikus) dan kelompok perlakuan II ( $200 \mathrm{mg} / \mathrm{kg}$ berat badan tikus).
\end{abstract}

Kata Kunci: skrining fitokimia; antidiabetes; daun nasi

\section{ABSTRACT}

Research about phytochemical screening and antidiabetic activity inside rice leaf extract (phrynium capitatum) had been conducted. Objective of this research was to find phytochemical and antidiabetic activity inside rice leaf extract. Research Methodology used for phytochemical screening was testting of alkaloids, phenolics, flavonoids, saponins, steroids and triterpenoids. While antidiabetic activity testing was carried out on white rats induced by alloxan treatment. Based on phytochemical screening tests of rice leaf extract, components obtained are alkaloid compounds, flavonoids, phenolics and steroids. The results of testing the antidiabetic activity of rice leaf extract in alloxan induced mice by administering $100 \%$ rice leaf extract; 200 and $300 \mathrm{mg} / \mathrm{kg}$ body weight of rats had a percent decrease in blood sugar concentration, respectively 29.01; 34.07 and $42.03 \%$. The most effective group providing antidibetic effect is the treatment group III (300 $\mathrm{mg} / \mathrm{kg}$ body weight of rats) when compared to the treatment group I (100 mg / kg body weight of rats) and treatment group II (200 mg / kg body weight of rats).

Keywords: phytochemical screening; antidiabetic; rice leaves

\section{Received: 23-07-2020, Accepted: 28-07-2020, Online: 20-08-2020}

\section{PENDAHULUAN}

Penyakit diabetes mellitus (DM) termasuk salah satu pembunuh terbesar di Asia tenggara dan Pasifik barat. Menurut data World Health Organizatin (WHO) jumlah penderita diabetes di Indonesia menempati urutan ke-6 di dunia setelah India, China, Rusia, Jepang dan Brasil. Pada tahun 2012 kematian yang disebabkan oleh penyakit diabetes sebesar 1,5 juta orang. Secara global, diperkirakan 422 juta orang dewasa hidup dengan diabetes pada tahun 2014 ( WHO, 2016). Diabetes mellitus adalah sindroma yang ditandai oleh gula darah yang tinggi (hiperglikemia) karena gangguan produksi, sekresi insulin atau resistensi insulin. Diabetes Mellitus dapat dibedakan atas iabetes mellitus tipe 1 (DM-1) atau insulin-dependent diabetes mellitus (IDDM) dan diabetes mellitus tipe 2 (DM-2) atau noninsulin-dependent diabetes mellitus (NIDDM). Hasil

\section{*Corresponding author:}

rorongjohnly@yahoo.com 
penelitian menunjukkan tingkat DM-1 sekitar 10-20\% dan DM-2 adalah $80-90 \%$ dari seluruh penderita diabetes (Widowati, 2008).

Penggunaan tumbuhan herbal sebagai obat diabetes mellitus yang sudah pernah diteliti terdiri dari 26 Jenis Tumbuhan, terdiri dari 15 Ordo dan 20 Famili. Jenis tumbuhan ini antara lain: Phyllanthus niruri, Ficus Septica, Moras alba, Alstonia scholaris, Catharanthus roseus, Strychnos ligustrina, Taraxacum officinale, Momordica charantia, Morinda citrifolia, Srobilanthes crispus, Coleus scutellariioides, Orthosipon stamineus, Physalis minima, Centella asiatica, Averrhoa carambola, Theobroma cacao, Psidium guajava, Syzigium polyanthum, Syzigium cumimi, Carica Papaya, Persea Americana, Cinnamomun burmanni, Tinospora crispa, Phaseolus vulgaris, Allium cepa, Aloe vera (Simanjuntak, 2018).

Di daerah Sulawesi Utara daun nasi adalah daun yang biasa digunakan sebagai pengemas atau pembungkus beras kemudian di rebus menjadi nasi. Nasi yang dibungkus dengan daun nasi disebut sebagai nasi bungkus. Konsumsi nasi bungkus, menggantikan nasi biasa telah dipercaya dapat menurunkan kadar gula darah bagi penderita diabetes, bagi sebagian masyarakat Minahasa.

Penelitian sebelumnya dari ekstrak daun nasi dilakukan oleh Wijaya (2014) tentang skrining fitokimia dan aktivitas antioksidan dengan metode DPPH (1,1 -difenil-2- pikrilhidrazil-). Dari hasil penelitian yang telah dilakukan kadungan senyawa fitokimia yang terkandung dalam ekstrak daun nasi yaitu alkaloid, fenolik, flavonoid, saponin dan steroid, dengan aktivitas antioksidan pada konsentrasi 250, 500, 750, dan $1000 \mu \mathrm{g} / \mathrm{mL}$ berturut-turut sebesar 19.58, 43.8, 53.96, dan $65.77 \%$.

Penelitian ini bertujuan untuk mengetahui kandungan fitokimia dan aktivitas antidiabetes ekstrak daun nasi. Pengujian fitokimia akan dilakukan dengan pengujian alkaloid, fenolik, flavonoid, saponin, steroid dan triterpenoid. Sedangkan pada pengujian antidiabetes akan dilakukan perlakuan pada tikus putih. Diharapkan penelitian ini akan dapat mengekplorasi potensi alam dan kearifan lokal herbal guna mendapatkan alternatif obat diabetes yang mudah dan terjangkau.

\section{METODE PENELITIAN}

\section{Alat dan Bahan}

Alat yang digunakan adalah blender, ayakan, kertas saring, rotary evaporator, cawan, desikator, kayu pengaduk, oven, timbangan, erlenmeyer, spatula, tabung reaksi, pipet tetes, aluminium foil, botol reagen, gelas ukur, labu takar, gelas piala, alat suntik, alat sonde, kapas luka, tissu, keranjang, Gluko DrTM Blood Glucose Test Meter, Gluko DrTM Blood glucose Test Strips. Bahan tumbuhan yang digunakan adalah daun nasi. Bahan kimia yang digunakan adalah etanol $95 \%$, ammonia, aquades, kloroform, asam sulfat, besi(III) klorida $1 \%$, serbuk magnesium, asam klorida $1 \mathrm{~N}$, asam asetat, pereaksi dragendorff, pereaksi mayer, avicel 101, aerosil, glibenklamid, carboxy methyl cellulose (CMC-Na), asam sitrat, sodium sitrat, Aloksan, 15 ekor tikus sebagai bahan uji.

\section{Preparasi}

Sampel yang diteliti adalah daun nasi yang diambil dari Kelurahan Pangolombian, Kecamatan Tomohon Selatan, Kota Tomohon, Provinsi Sulawesi Utara. Sampel daun nasi dibersihkan terlebih dahulu lalu dikering anginkan selama 1 bulan dan dihaluskan dengan menggunakan blender kemudian diayan dengan ayakan 65 mesh sampai diperoleh serbuk.

\section{HASIL DAN PEMBAHASAN}

\section{Ekstraksi}

Metode ekstraksi yang digunakan dalam penelitian ini adalah metode maserasi karena metode tersebut merupakan salah satu metode umum dalam proses ekstraksi bahan alam, selain itu metode maserasi lebih sedehana dan mudah. Menurut Harmita \& Radji (2008), maserasi merupakan cara sederhana yang dapat dilakukan dengan cara merendam serbuk simplisia dalam 
pelarut. Pelarut akan menembus dinding sel dan masuk kedalam rongga sel yang mengandung zat-zat aktif sehingga zat aktif akan larut. Pelarut yang digunakan etanol karena bersifat polar, universal, dan mudah didapat. Senyawa polar merupakan senyawa yang larut didalam air. Senyawa metabolit sekunder yang akan diambil pada daun nasi bersifat polar sehingga proses ekstraksi menggunakan pelarut polar (Harborne, 1987).

Tabel 1. Hasil Ekstraksi

\begin{tabular}{cccc}
\hline $\begin{array}{c}\text { Berat serbuk daun } \\
\text { nasi }(\mathrm{g})\end{array}$ & $\begin{array}{c}\text { Berat ekstrak } \\
\text { kental }(\mathrm{g})\end{array}$ & $\begin{array}{c}\text { Rendemen } \\
(\%)\end{array}$ & Warna Ekstrak \\
\hline 200 & 20.234 & 10.117 & Hijau kehitaman \\
\hline
\end{tabular}

Dalam penelitian ini perendaman sampel dengan etanol 95\% dilakukan selama 5 hari dan penyaringan sebanyak 3 kali sehingga didapatkan ekstrak etanol cair. Selanjutnya dilakukan penguapan pelarut dari filtrat yang diperoleh selama perendaman atau maserasi menggunakan rotary evaporator pada suhu $79^{\circ} \mathrm{C}$, kemudian dimasukkan kedalam oven pada suhu $45^{\circ} \mathrm{C}$ dan didapatkan ekstrak kental sebanyak 20.234 gram. Rendemen yang didapatkan dalam penelitian ini sebesar $10.117 \%$. Ada beberapa faktor yang mempengaruhi banyaknya rendemen yang diperoleh dari ekstraksi maserasi, contohnya lama perendaman sampel dalam ekstraksi. Menurut Sembiring (2011), semakin lama perendaman sampel dengan pelarut maka kontak pelarut dengan sampel akan semakin baik sehingga komponen dalam sampel dapat terekstrak dengan maksimal, hal ini menyebabkan rendemen yang didapatkan semakin besar.

\section{Skrining Fitokimia}

Skrining fitokimia pada penelitan ini dilakukan berdasarkan pengujian menurut Harborne (1987). Berdasarkan pengujian yang telah dilakukan kandungan fitokimia yang terkandung dalam daun nasi dapat dilihat pada tabel 2.

Tabel 2. Hasil Skrining Fitokimia Ekstrak Daun Nasi

\begin{tabular}{lll}
\hline $\begin{array}{l}\text { Golongan/ } \\
\text { Senyawa }\end{array}$ & \multicolumn{1}{c}{ Hasil Skrining } & \multicolumn{1}{c}{ Standar } \\
\hline Alkaloid & - & Endapan putih (Pereaksi Mayer) \\
\cline { 2 - 3 } & + & Endapan Kuning-merah (Pereaksi Dragendrof) \\
\hline Fenolik & + & Warna merah, hijau, ungu atau hitam pekat \\
\hline Flavonoid & + & Warna merah, kuning, atau jingga \\
\hline Steroid & + & Warna merah atau hijau \\
\hline Saponin & - & Terbentuk busa yang stabil \\
\hline Triterpenoid & - & Warnah merah atau ungu \\
\hline
\end{tabular}

\section{Uji Aktivitas Antidiabetes}

Uji aktivitas antidibetes dari ekstrak kering daun nasi (Phrynium capitatum) dilakukan pada tikus putih yang hiperglikemi hasil induksi aloksan dengan dosis $150 \mathrm{mg} / \mathrm{kg}$ BB. Aloksan dipilih sebagai diabetogen dalam penelitian ini dikarenakan aloksan di dalam tubuh mengalami metabolisme oksidasi reduksi menghasilkan radikal bebas dan radikal aloksan, radikal ini mengakibatkan kerusakan sel beta pankreas (Santika, 2017). Hewan uji dikatakan hiperglikemi yaitu hewan dengan kadar gula darah $\geq 200 \mathrm{mg} / \mathrm{dL}$ setelah induksi aloksan. Pengujian ekstrak daun nasi ini dilakukan selama 3 hari. Selama waktu 3 hari tersebut semua tikus memperoleh perlakuan sesuai dengan kelompok uji masing-masing. Berikut adalah tabel dan grafik efektivitas ekstrak kering daun nasi terhadap kadar gula darah tikus selama 3 hari. 
Tabel 3. Data rata - rata pengukuran kadar gula darah $(\mathrm{mg} / \mathrm{dL})$ dan standar deviasi pada berbagai kelompok perlakuan

\begin{tabular}{lccccc}
\hline \multirow{2}{*}{ Kelompok perlakuan } & \multicolumn{5}{c}{ Kadar gula darah $(\mathrm{mg} / \mathrm{dL}) \pm$ standar deviasi } \\
\cline { 2 - 6 } & $\begin{array}{c}\text { Sebelum } \\
\text { Induksi }\end{array}$ & $\begin{array}{c}\text { Setelah } \\
\text { Induksi }\end{array}$ & Hari ke-1 & Hari ke-2 & Hari ke-3 \\
\hline \multirow{2}{*}{ CMC-Na 5\% } & 84 & 302 & 306 & 300.33 & 298.33 \\
& \pm .56 & 30.41 & 29.72 & 32.81 & 43.89 \\
\hline Glibenklamid 0.45 & 88.33 & 292.33 & 209.67 & 181.33 & 146.33 \\
mg/kg BB & \pm & \pm & \pm & \pm & \pm \\
& 12.06 & 27.3 & 25.11 & 28.99 & 33.29 \\
\hline Ekstrak kering daun & 100.67 & 301 & 279 & 249.33 & 213.67 \\
nasi 100 mg/kg BB & \pm & \pm & \pm 8.54 & \pm & \pm \\
& 9.29 & 8.72 & & 4.04 & 6.66 \\
\hline Ekstrak kering daun & 96.67 & 286.67 & 264.33 & 230.67 & 189 \\
nasi 200 mg/kg BB & \pm & \pm & \pm & \pm & \pm \\
& 6.03 & 21.83 & 19.76 & 19.22 & 26.06 \\
\hline Ekstrak kering daun & 80.67 & 259.3 & 229.67 & 190.33 & 150.33 \\
nasi 300 mg/kg BB & \pm & 3 & \pm & \pm & \pm \\
& 19.04 & \pm 15.37 & 19.04 & 24.17 & 17.04 \\
\hline
\end{tabular}

*) Data ditampilkan dalam bentuk rata-rata \pm SD dengan jumlah data $(n)=5$

Berdasarkan Tabel 3 diatas menunjukkan bahwa rata-rata kadar gula darah awal sebelum induksi adalah 80.67-100.67 mg/dL, kadar glukosa ini termasuk kadar gula darah normal karna belum di berikan perlakuan. Setelah diinduksi aloksan semua kelompok perlakuan mengalami kenaikan gula darah sekitar 259.33-302 mg/dL. Hal tersebut disebabkan karena mekanisme aloksan secara spesifik merusak sel $\beta$ pankreas yang mensekresi hormon insulin, menunjukkan bahwa induksi aloksan bertujuan untuk mengkondisikan tikus dalam keadaan eksperimental diabetes dengan metode perusakan struktur pankreas. Kondisi eksperimental diabetes akan mengakibatkan tikus normal menjadi tikus penderita DM dengan ditandai salah satu ciri diagnosa klinis penurunan berat badan (Santika, 2017).

Data kadar gula darah tikus dalam penelitian ini dianalisis statistik menggunakan One Way Anova yang kemudian di lanjutkan dengan Post Hoc Test metode Bonferroni $(p<0.05)$. Hasil uji statistik dapat dilihat di lampiran 7 tabel 12 dan tabel 13. Uji One Way Anova menunjukkan bahwa dari data pengujian kadar gula darah pada tikus terdapat minimal satu pasang kelompok perlakuan yang berbeda bermakna $(p<0.05)$. Untuk mengetahui kelompok perlakuan yang berbeda, dilakukan analisis statistik Post Hoc Test metode Bonferroni.

Dari hasil analisis Post Hoct Test metode Bonferroni terdapat perbedaan bermakna $(p<0.05)$ antara kelompok perlakuan kontrol negatif dengan kelompok perlakuan kontrol positif, perlakuan II, dan perlakuan III. Hasil analisis kelompok perlakuan kontrol positif tidak terdapat perbedaan bermakna ( $p>0.05)$ dengan kelompok perlakuan I, perlakuan II, dan perlakuan III. Berdasarkan hasil analisis tersebut, dapat disimpulkan bahwa ekstrak kering daun nasi memberikan efek penurunan kadar gula darah sebanding dengan kontrol positif (glibenklamid).

Berdasarkan Gambar 8 kelompok CMC- Na 5\% menujukkan kadar gula darah dari awal sampai hari ke-3 perlakuan tidak terlihat penurunan yang besar. Penurunan kadar gula darah hanya sebesar $3.67 \pm 14.01 \mathrm{mg} / \mathrm{dL}$ selama 3 hari. Kelompok positif dalam penelitian ini adalah Glibenklamid. Glibenklamid dipilih sebagai terapi pembanding ekstrak etanol daun nasi karena dapat merangsang sekresi insulin di kelenjar pankreas. Dosis glibenklamid yang digunakan adalah $0.1 \mathrm{mg} / 220 \mathrm{~g} \mathrm{BB}$. Dosis tersebut digunakan berdasarkan dosis efektif oral pada manusia, yaitu 5 
$\mathrm{mg} /$ hari yang kemudiaan dikonversikan ke dosis tikus. Pada kelompok positif terjadi penurunan kadar gula darah sebesar $146 \pm 8.19 \mathrm{mg} / \mathrm{dL}$ selam 3 hari.

\section{Efektifitas ekstrak kering daun nasi terhadap kadar gula darah tikus (mg/dL)}

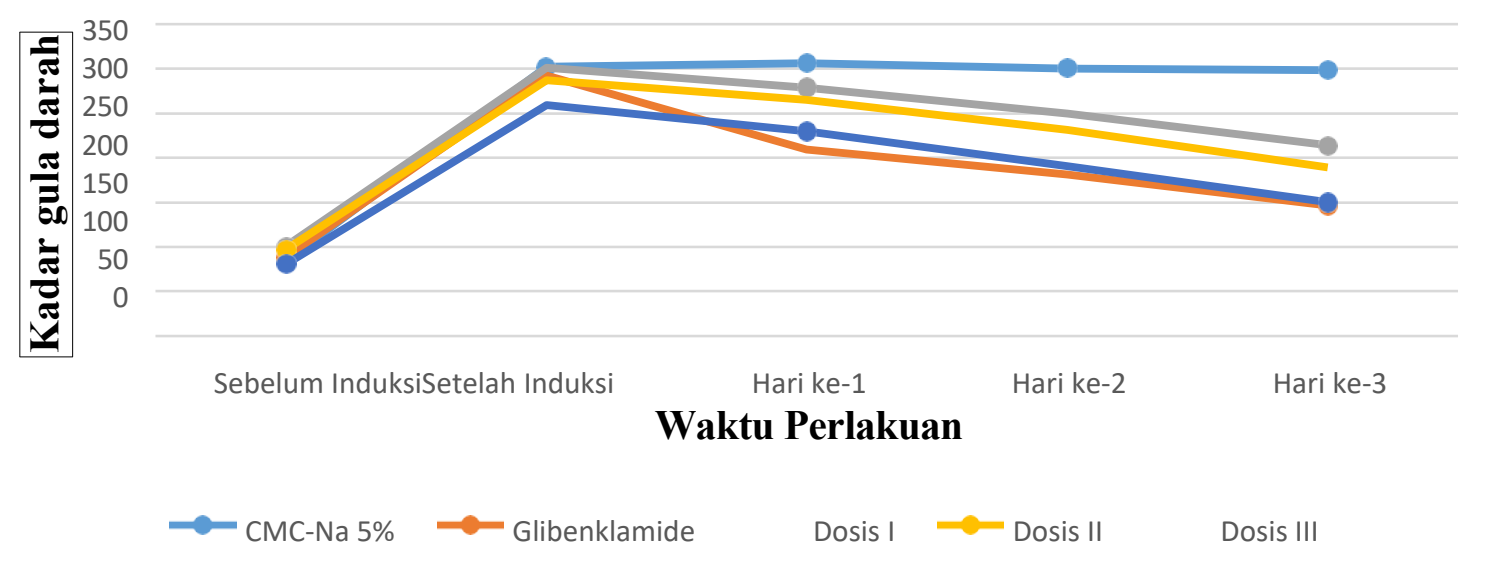

Gambar 1. Grafik efektifitas ekstrak kering daun nasi terhadap kadar gula darah tikus $(\mathrm{mg} / \mathrm{dL})$

Selanjutnya kelompok dosis I, yakni kelompok tikus diabetes yang mendapat ekstrak kering daun nasi dengan dosis 100 mg/260 gram BB juga mampu menurunkan kadar gula darah yang dimana pemberian ekstrak kering daun nasi mengalami penurunan kadar gula darah sebesar $87.33 \pm 2.08 \mathrm{mg} / \mathrm{dL}$ dalam kurun waktu 3 hari.

Kelompok dosis II, yakni kelompok tikus diabetes yang mendapat ekstrak kering daun nasi dengan dosis 200 mg/260 gram BB mengalami penurunan kadar gula darah yang tidak terlalu jauh dari dosis I, dimana pemberian ekstrak kering daun nasi mengalami penurunan kadar gula darah sebesar $97.67 \pm 4.93 \mathrm{mg} / \mathrm{dL}$ dalam kurun waktu 3 hari. Kelompok dosis III, yakni kelompok tikus diabetes yang mendapat ekstrak kering daun nasi dengan dosis $300 \mathrm{mg} / 260$ gram BB juga mengalami penurunan kadar gula darah yang tidak terlalu jauh dari dosis I dan dosis II, dimana pemberian ekstrak kering daun nasi mengalami penurunan kadar gula darah sebesar $109 \pm 6$ $\mathrm{mg} / \mathrm{dL}$ dalam kurun waktu 3 hari. Analisis data aktivitas antidiabetes daun nasi ditunjukkan dengan persen penurunan kadar gula (\%GL). Hasil perhitungan \%GL dapat kita lihat pada tabel 4.

Tabel 4. Analisis data \% Glucose Lowering (\%GL)

\begin{tabular}{llccc}
\hline \multirow{2}{*}{ Kelompok perlakuan } & \multicolumn{3}{c}{ Rata-rata gula darah } & \\
\cline { 2 - 4 } & $\begin{array}{c}\text { Setelah } \\
\text { Induksi }(\mathrm{X})\end{array}$ & Hari ke-3 $(\mathrm{Y})$ & $(\mathrm{X}-\mathrm{Y})$ & $\% \mathrm{GL}$ \\
\hline CMC-Na 0,5\% & 302 & 298.33 & 3.67 & 1.22 \\
\hline Glibenklamid 0.45 mg/kg BB & 292.33 & 146.33 & 146 & 49.94 \\
\hline Ekstrak kering daun nasi 100 mg/kg BB & 301 & 213.67 & 87.33 & 29.01 \\
\hline Ekstrak kering daun nasi 200 mg/kg BB & 286.67 & 189 & 97.67 & 34.07 \\
\hline Ekstrak kering daun nasi 300 mg/kg BB & 259.33 & 150.33 & 109 & 42.03 \\
\hline
\end{tabular}

Dari uraian tersebut dapat disimpulkan bahwa ekstrak kering daun nasi mampu menurunkan kadar gula darah tikus yang hiperglikemi, namun jika dilihat penurunan kadar gula 
darah dari obat glibenklamid lebih besar, ini berarti kemampuan ekstrak daun nasi sebagai antidiabetes sedikit lemah, tapi jika di lihat dari pemberian dosis semakin tinggi dosis yang diberikan maka semakin besar penurunan kadar gula darah yang didapatkan. Jadi untuk mendapatkan penurunan kadar gula darah yang lebih besar maka dosis pemberian dari ekstrak daun nasi harus semakin besar.

Penurunan kadar glukosa darah dengan pemberian ekstrak etanol daun nasi dapat disebabkan oleh adanya senyawa biokatif yang terkandung dalam daun nasi yang dapat mencegah terjadinya oksidasi pada sel $\beta$ pankreas sehingga kerusakan dapat diminimalkan. Berdasarkan hasil pengujian skrining fitokimia dapat dilihat bahwa beberapa senyawa yang terkandung dalam ekstrak daun nasi berpotensi sebagai obat diabetes mellistus antara lain, senyawa fenolik, flavonoid, dan steroid.

Menurut peneltian yang dilakukan oleh Rochman et al. (2016), potensi fenolik sebagai obat kadar gula darah tinggi dapat terjadi karena adanya inhibitor a-glukosidae. A-glukosidae merupakan salah satu enzim yang memecah karbohidrat menjadi partikel gula lebih kecil yang disebut glukosa, dan kemudian akan diserap oleh organ dan digunakan sebagai energi. Inhibitor aglukosidae (AGI) kadang dikenal sebagai penghambat pati yang merupakan obat antidiabetes untuk mengurangi kadar gula darah setelah makan. Inhibitor a-glukosidae bekerja secara kompetitif dan reversibel dalam menghambat alfa-glukosidase, enzim usus. Ini akan memperlambat pencernaan karbohidrat serta menunda penyerapan glukosa yang juga memperlambat mengurangi peningkatan dalam kadar glukosa darah setelah makan secara efektif sepanjang hari.

Di bidang farmasi dan medis, flavonoid berfungsi sebagai antimikroba, antivirus, antioksidan, antihipertensi, merangsang pembentukan esterogen mongobati gangguan fungsi hati dan juga berperan penting dalam aktivitas antidiabetes, yaitu menurunkan kadar gula darah secara segnifikan. Lima bentuk flavonoid, yaitu myrciacitrin I-V yang diisolasi dari daun Myrcia multiflora D.C (Myrtaceae) semuanya menunjukkan aktivitas antidiabetes. Flavonoid juga dapat menurunkan kadar gula darah dengan kemampuannya sebagai antioksidan, flavonoid bersifat protektif terhadap sel $\beta$ sebagai penghasil insulin serta dapat meningkatkan sensivitas insulin (Jung, et al. 2006).

Steroid merupakan komponen aktif dalam tumbuhan yang telah digunakan untuk penyakit diabetes, gangguan menstruasi, antibakteri dan antivirus. Dibidang farmasi steroid banyak dimanfaatkan terkait fungsinya pada hormon reproduksi (Savithramma, et al. 2011).

\section{SIMPULAN}

Berdasarkan pengujian skrining fitokimia dan aktivitas antidiabetes dari ekstrak daun nasi dapat dilihat bahwa komponen senyawa aktif yang terkandung dalam ekstrak etanol daun nasi adalah, alkaloid, flavonoid, fenolik dan steroid. Berdasarkan pengujian aktivitas antidiabetes ekstrak daun nasi memberikan efek penurunan kadar gula darah. Kelompok yang paling efektif memberikan efek antidibetes adalah kelompok perlakuan III (300 mg/kg BB) bila dibandingkan dengan kelompok perlakuan I (100 mg/kg BB) dan kelompok perlakuan II (200 mg/kg BB), dengan persen penurunan kadar gula darah sebesar 42.03 ; 34.07, dan $29.01 \%$.

\section{DAFTAR PUSTAKA}

Azrimaidaliza. 2011. Asupan Zat Gizi dan Penyakit Diabetes Mellitus. Jumal Kesehatan Masyarakat. 6(1) : 36-41. 
BPOM. 2001. Peraturan Kepala Badan Pengawas Obat dan Makanan Republik Indonesia Tentang Pengawasan Klaim dalam Label dan Iklan Pangan Olahan. BPOM, Jakarta.

Depkes RI. 1993. Pedoman Pengujian dan Pengembangan Fitokimia: Penapisan Farmakologi, Pengujian Fitokimia, dan Pengujian Klinik. Yayasan Perkembangan Obat Bahan Alam, Jakarta.

Depkes RI. 1995. Farmakope Indonesia. Edisi IV. Departemen Kesehatan Republik Indonesia, Jakarta.

Ditjen POM. 1986. Sediaan Galenik. Departemen Kesehatan RI, Jakarta.

Harborne, J.B. 1987. Metode Fitokimia Cara Modern Menganalisis Tumbuhan. Edisi ke-2. Diterjemahkan oleh Kosasih Padmawinata dan Imam Sudiro. ITB, Bandung.

Harborne, J.B. 1984. Phitochemical Method.

Chapman and Hall Itd, London.

Harmita \& Radji, M. 2008. Kepekaan Terhadap Antibiotik. Dalam: Buku Ajar Analisis Hayati, Eds.3.EGC,Jakarta.

Heyne, K. 1987. Tumbuhan Berguna Indonesia. Badan Litbang Departemen Kehutanan, Jakarta.

Irwan, F. 2011. Aktivitas Antidiabetes Dan Analisis Fitokimia Ekstrak Air Dan Etanol Daun Wungu (Graptophyllum Pictum (L.) Griff). [Skripsi]. Departemen Biokimia Institut Pertanian Bogor, Bogor.

Ismail, J., Max, R. J. R., \& Feti, F. 2012. Penentuan Total Fenolik dan Uji Aktivitas Antioksidan pada Biji dan Kulit Buah Pinang Yaki (Areca Vestiaria Giseke). Jurnal Ilmiah Sains. 12(2) : 84-88.

Jung, M., Park, M., Lee, H. C., Kang, Y., \& Kim, S.K. 2006. Antidiabetic Agents from Medicinal Plants. Current Medicinal Chemistry. 13 : 1203-1218.

Larsen, K. 1978. A new species of pachelophrynium from Northern Thailand. Bot. Notiser. 131 : 83-84.

Mataputun, S. P., Johnly, A.Rorong. \& Julius, Pontoh. 2013. Aktivitas Inhibitor a- Glukosidase Ekstrak Kulit Batang Matoa (Pometia pinnata. Spp.) sebagai Agen Antihiperglikemik. Jurnal Mipa UNSRAT Online. 2(2) : 119-123.

Oktaria, Y.E., EM, S. \& Tanti, A. 2013. Uji Aktivitas Antidiabetes Ekstrak Etanol Biji Alpukat (Persea Americana Mill.) Terhadap Tikus Galur Wistar yang Diinduksi Aloksan. Fakutas Farmasi Universitas Muhammadiyah Surakarta, Surakarta.

Putranto, U.D. 2015. Pangan Fungsional dari Jamur Tiram. Penyuluhan Jamur Pangan di Desa Argo Peni, Kecamatan Ayah, Kabupaten Kebumen. Universitas Jenderal Soedirman, Purwakarta.

Robak, J. \& Gryglewski, R.J. 1988. Flavonoids are Scavengers of Super Oxide Anions. J Biochemistry and Pharmacology. 37 : 837-841. 
Rochman, J., Tri, A.S. \& Ranadewi, A. A. I. 2016. Studi Aktivitas Antioksidan dan Inhibitor aGlikosidae Ekstrak Fenolik Daun Bugur (Lagerstroemia speciose) dari Taman Nasional Meru Betiri. Jurnal IImu Dasar. 17(1) : 39-46.

Rorong, J. A. \& Edy, S. 2010. Analisis Fitokimia Enceng Gondok (Eichhornia Crassipes) dan Efeknya Sebagai Agen Photoreduksi Fe3 ${ }^{+}$. Chemistry Progress. 3(1) : 33-41.

Rorong, J. A., Sudiarso, Budi, P., Jeany, P.M. \& Edy, S. 2012. Phytochemical Analysis Of Water Hyacinth (Eichhornia Crassipes) Of Agricultural Waste As Biosensitizer For Ferri Photoreduction. AGRIVITA. 34(2) : 152-160.

Santika, L.N. 2017. Uji Antihiperglikemia Ekstrak Etanol Buah Pepino (Solanum muricatum Aiton) Pada Tikus Jantan Galur Wistar Yang Diinduksi Dengan Aloksan. [Skripsi]. Fakultas Farmasi, Universitas Setia Budi, Surakarta.

Savithramma, N., Rao, M.L., \& Suhrulatha, D. 2011. Screening of Medicinal Plants for Secondary Metabolites. Middle East Journal of Scientific Research. 8(3) : 579- 584.

Sembiring, D.M. 2011, Isolasi Dan Analisis Komponen Kimia Minyak Atsiri Dari Daun Tumbuhan Binara (Artemisia Vulgaris L.) Di Daerah Kecamatan Sibolangit Kabupaten Deli Serdang Dengan GC-MS Dan FT-IR. [Tesis]. MIPA Universitas Sumatera Utara, Medan.

Septiany, E. 2016. Pengaruh ekstrak etanol semut jepang (Tenebrio molitor L) terhadap kadar glukosa darah pada tikus putih jantan galur wistar yang diinduksi aloksan. [Skripsi]. Fakultas Farmasi, Universitas Setia Budi, Surakarta.

Sharma A. 2012. Transdermal Approach of Antidiabetic Drug Glibenclamide: A Review. International Journal of Pharmaceutical Research and Development, 3(11) : 25-32.

Sidik \& Mudahar, H. 2000. Ekstraksi Tumbuhan Obat, Metoda dan Faktor-Faktor yang Mempengaruhi Mutu Produksinya, Makalah disajikan dalam Prosiding Seminar PERHIPBA Pemanfaatan Bahan Obat Alami III, Jakarta.

Simanjuntak, H. A. 2018. Pemanfaatan Tumbuhan Obat Diabetes Mellitus Di Masyarakat Etnis Simalungun Kabupaten Simalungun Provinsi Sumatera Utara. Jurnal Biologi, Lingkungan, Industri, Kesehatan. 5(1) : 59-71.

Sirois, M. 2005. Laboratory animal medicine: Principles and procedures. United States of America: Mosby, Inc, Amerika.

Trisnawati, K, T. \& Soedijono, S. 2012. Faktor Risiko Kejadian Diabetes Melitus Tipe II Di Puskesmas Kecamatan Cengkareng Jakarta Barat Tahun 2012. Jurnal IImiah Kesehatan, 5(1).

Wardani, N. P. 2016. Uji Aktivitas Antidiabetes Ekstrak Kering Biji Mahoni Terstandar (Swietenia mahagoni Jacq) pada Mencit yang Diinduksi Aloksan. [Skripsi]. Universitas Airlangga, Surabaya.

WHO. 2016. Global Report On Diabetes. World Health Organization, France. 
Widowati, W. 2008. Potensi Antioksidan sebagai Antidiabetes. JKM. 7(1) : 1-11.

Wijaya, D. P., Jessy, E. P. \& Jemmy, A. 2014. Skrining Fitokimia dan Uji Aktivitas Antioksidan dari Daun Nasi (Phrynium capitatum) dengan Metode DPPH (1,1- difenil-2-pikrilhidrazil). Jurnal MIPA UNSRAT Online. 3(1) : 11-15. 